\title{
PREFERENSI LEMBAGA PENDIDIKAN ISLAM DALAM MEMILIH PAYROLL DI BANK SYARIAH
}

\author{
Gianisha Hardiyani \\ Program Studi Perbankan Syariah Fakultas Ekonomi Islam, Universitas Djuanda Bogor \\ Email: gianishardiyani22@gmail.com \\ Tuti Kurnia \\ Program Studi Perbankan Syariah Fakultas Ekonomi Islam, Universitas Djuanda Bogor \\ Email: tuti.kurnia@unida.ac.id \\ Sahlan Hasbi \\ Program Studi Perbankan Syariah Fakultas Ekonomi Islam, Universitas Djuanda Bogor \\ Email: sahlan.hasbi@gmail.com
}

\section{ARTICLE HISTORY}

Received:

10 Desember 2018

Accepted:

29 Desember 2018

Online available:

31 Desember 2018

Keywords:

Bank Syariah, Preferences, Payroll, Islamic educational institutions.
This study aims to determine the most dominant factors that affecting the preferences of Islamic educational institutions in choosing payroll in Islamic banks. The research method used a quantitative approach with factor analysis technique. Data collection techniques used questionnaires and interview techniques from 30 Islamic educational institutions in Sukabumi. The results of this study indicate that service, facilities, image, religion, and reference groups are the most dominant factor or the main factor for the preference of Islamic educational institutions in choosing payroll in Islamic banks. While role factor and status, product, promotion, location and knowledge are the supporting factor for preference of Islamic education institution in choosing payroll in syariah bank.

\section{ABSTRAK}

Kata Kunci:

bank syariah, preferensi, payroll, lembaga pendidikan Islam
Penelitian ini bertujuan untuk mengetahui faktor-faktor paling dominan yang mempengaruhi preferensi lembaga pendidikan Islam dalam memilih payroll di bank syariah. Metode penelitian menggunakan pendekatan kuantitatif dengan teknik analisis faktor. Teknik pengumpulan data menggunakan teknik kuesioner dan wawancara yang berasal dari 30 lembaga pendidikan Islam yang ada di Sukabumi. Hasil penelitian ini menunjukan bahwa pelayanan, fasilitas, image, agama, dan kelompok referensi merupakan faktor yang paling dominan atau faktor utama untuk 
preferensi lembaga pendidikan Islam dalam memilih payroll di bank syariah. Sedangkan faktor peran dan status, produk, promosi, lokasi dan pengetahuan merupakan faktor pendukung untuk preferensi lembaga pendidikan Islam dalam memilih payroll di bank syariah.

\section{PENDAHULUAN}

Jawa Barat khususnya Sukabumi merupakan kota mayoritas penduduk muslim dan merupakan urutan ke-3 sebagai jumlah mayoritas muslim terbesar di Jawa Barat, berdasarkan data dari Badan Pusat Statistik Sukabumi Dalam Angka 2017 jumlah penduduk adalah sebanyak 2.422.113 orang. Tingginya jumlah penduduk di Sukabumi serta mayoritas penduduknya adalah muslim seharusnya menjadi sebuah potensi untuk bank syariah maju di wilayah Sukabumi (Badan Pusat Statistik Sukabumi, 2017).

Potensi bank syariah dapat digali dengan melihat banyaknya lembaga-lembaga berbasis Islam yang berdiri di Sukabumi, lembaga-lembaga ini dapat dikategorikan seperti banyaknya sekolah-sekolah berbasis Islam seperti Pondok Pesantren, Madrasah (MI) dan sekolah Islam. Jumlah yang didapatkan dari Dinas Pendidikan Kabupaten Sukabumi yaitu terdapat 321 lembaga pendidikan Islam di kabupaten Sukabumi dengan jumlah tenaga pengajar sebanyak 2960 orang (Dinas Pendidikan Kabupaten Sukabumi, 2017).

Lembaga perbankan adalah lembaga yang terpenting dalam sistem perekonomian modern. Tidak satupun negara yang dapat menjalankan kegiatan perekonomiannya tanpa melibatkan perbankan, karena perbankan adalah sebagai penghubung antara surplus unit dengan defisit unit dengan cara menghimpun dana dari masyarakat dan kemudiaan disalurkan dari masyarakat pula dalam bentuk kredit (Hasbi, 2016:222). Oleh karenanya, peran masyarakat dalam hal lembaga pendidikan Islam sangatlah penting karena hal ini dapat bermanfaat untuk masyarakat, karena dananya disalurkan untuk yang membutuhkan kredit serta membantu perkembangan bank.

Salah satu yang mendorong berkembangnya perbankan syariah adalah dengan bertumbuhnya aset pada bank syariah yakni meningkatnya penghimpunan DPK atau dana pihak ketiga bank syariah. hal ini telah menjelaskan jika lembaga pendidikan Islam memanfaatkan bank syariah sebagai lembaga penyalur gajinya, hal ini dapat membantu bank dalam meningkatkan aset DPKnya (Ibrahim, 2013:2).

Peran lembaga pendidikan Islam sangatlah penting dalam memajukan perbankan syariah di wilayah Sukabumi. Kontribusi dan peran serta dalam memajukan perbankan 
syariah dapat dilaksanakan dengan cara lembaga pendidikan Islam menggunakan jasa bank syariah sebagai contohnya adalah produk jasa payroll, hal ini dapat membantu DPK perbankan syariah.

Perbankan syariah membutuhkan dukungan yang lebih dari masyarakat untuk mewujudkan bank yang beroperasi secara maksimal. Salah satu dari sekian banyak yang dapat untuk meningkatkan peran serta seluruh lapisan masyarakat adalah dengan menggunakan payroll di bank syariah, dengan payroll tersebut maka diharapkan para guru menyimpan minimal $10 \%$ dari gajinya, hal ini dapat membuat terwujudnya peningkatan untuk DPK bank syariah. Maka dari itu, informasi menganai preferensi lembaga pendidikan Islam merupakan hal yang sangat penting yang harus diperhatikan, sehingga dapat mengetahui faktor-faktor apa yang memiliki hubungan dengan nasabah dalam studi kasus ini lembaga pendidikan Islam dalam menggunakan jasa bank syariah.

\section{LANDASAN TEORI}

\section{Preferensi}

Menurut Kotler, preferensi konsumen yaitu menunjukan kesukaan konsumen itu sendiri terhadap suatu produk. Preferensi juga merupakan kesukaan atau kecenderungan hati kepada sesuatu, dan dapat diartikan juga pilihan seseorang terhadap berbagai pilihan produk, ataupun jasa yang dikonsumsinya (Kotler, 2000:154).

Preferensi juga dapat didefinisikan yaitu sebagai proses seseorang dalam memilih, baik itu memilih informasi atau memilih sesuatu yang lebih disukai, dan dapat diartikan juga sebagai konsumen yang menunjukan kesukaannya dari beberapa pilihan yang tersedia (Aisyah Erinda, 2016:89).

2. Lembaga Pendidikan Islam

Lembaga pendidikan Islam merupakan suatu organisasi atau tempat yang didalamnya menyelenggarakan pendidikan yang berbasis Islam, yang mempunyai struktur yang jelas serta bertanggung jawab atas terlaksananya sebuah pendidikan tersebut. Maka dari itu, lembaga tersebut haruslah memiliki suasana yang memungkinkan terlaksananya pendidikan dengan sangat baik menurut tugasnya masingmasing. (Bafadhol, 2017:60) Lembaga tersebut diwakili oleh pesantren, madrasah, dan sekolah Islam, ketiga institusi pendidikan ini mempunyai nama yang berbeda namun memiliki fungsi dan substansi yang sama.

\section{a. Pesantren}

Menurut istilah dapat dijelaskan bahwa pesantren merupakan tempat dimana dimensi ekstorik (penghayatan secara lahir) Islam diajarkan. Dapat dilihat dari wujud dan sistem yang berasal dari India, namun setelah Islam masuk dan menyebar di 
Indonesia, hal tersebut kemudian diambil oleh orang Islam. (Herman, 2013:146) Pesantren dibedakan menjadi dua, yaitu pesantren salafiyah dan pesantren modern.

b. Madrasah

Menurut Muhammad Rouf madrasah merupakan sebagai sekolah atau perguruan, yaitu terutama perguruan Islam, perguruan dalam hal ini diartikan sebagai lembaga pendidikan (Rouf, 2016:73). Dalam prakteknya madrasah memang tidak hanya mengajarkan mengenai ilmu-ilmu keagaaman, melainkan juga pengetahuan sekolah umum. Masyarakat mengenal dan memahami pengertian "madrasah" sebagai lembaga pendidikan yang menjadi tempat belajar agama karena memang madrasah berasah dari kata bahasa Arab dan tidak diterjemahkan ke dalam bahasa Indonesia (Rahmawati, 2016:157).

c. Sekolah Islam

Dunia pendidikan sekolah memiliki peran untuk mengembangkan dan mengasah kemampuan anak, baik itu di sekolah yang berlandaskan nilai agama atau biasa disebut sekolah Islam maupun di sekolah umum baik itu sekolah umum negeri maupun swasta. Dengan kata lain pengertian dari sekolah Islam atau pendidikan Islam yang secara terminologi agalah proses dalam mengubah suatu tingkah laku individu dalam kehidupan pribadi, masyarakat maupun lingkungan sekitarnya, dengan cara pengajaran sebagai aktivitas asasi dalam masyarakat (Agustina, 2013:4).

Jaringan sekolah Islam terpadu Indonesia atau di singkat JSIT juga mengemukakan tentang pengertian dari sekolah Islam terpadu yakni sekolah yang menyeimbangkan antara pendidikan agama dan pendidikan umum, namun dalam segi kualitas pun tidak kalah dengan sekolah umum.

3. Konsep Sistem dan Mekanisme Payroll di Bank Syariah

Pada umumnya, sesuai dengan tujuan dari bank itu sendiri, yaitu terdapat dua kegitan utama dalam perbankan, baik itu perbankan syariah maupun perbankan konvensional yaitu menghimpun dan menyalurkan dana. Namun adapula produk lain yang dikeluarkan oleh bank yaitu produk jasa lainnya (Haris 2015:10). Salah satu produk yang akan di bahas adalah produk payroll atau Sistem Penggajian. Pengertian payroll itu sendiri adalah sistem pemberian gaji karyawan secara elektronik dan masal yang pada umumnya melalui direct deposit atau transfer langsung ke rekening karyawan yang bisa dipantau secara real time (Atsari, 2013:27).

Setiap bank mempunyai strategi masing-masing dalam pengembangan produknya, bank syariah adalah dalam hal penghimpunan dana yaitu salah satu implementasinya adalah payroll merupakan salah satu strateginya. Bank syariah menggunakan strategi ini yaitu dengan menentukan kesepakatan bank dengan lembaga 
yang di ajak kerja sama untuk menentukan waktu yang sesuai kesepakatan. Dalam payroll ini, pihak bank hanya memberikan keringanan pada lembaga yang menggunakan jasa ini dalam memberikan gaji kepada karyawan nya maka pihak bank pula tidak menjanjikan memberikan keuntungan atas dana lembaga yang disimpan dan di putar kembali oleh bank (Ananta, 2016:22).

Payroll merupakan salah satu penghimpunan dana yang berprinsip wadi'ah dan Mudharabah, pengertian wadi'ah itu sendiri adalah menempatkan sesuatu yang ditempatkan bukan pada pemiliknya untuk di pelihara, wadi'ah juga berarti titipan murni yang di titipkan dari pihak satu ke pihak lain. Jika penitip ingin mengambil titipannya, maka badan hukum maupun individu harus mengembalikan kapanpun waktu yang dihendaki. Bank Muamalat Indonesia juga mengartikan wadi'ah itu sebagai titipan murni yang dengan seizin penitip boleh digunakan oleh bank, jika tidak ada izin, maka tidak boleh digunakan oleh pihak bank. Titipan murni ini dapat berupa uang, barang, maupun dokumen surat berharga (Aisyah, 2016:111) Dalam akad ini payroll bank syariah tidak boleh mensyaratkan pembagian bagi hasil keuntungan atas pemanfaatan harta tersebut, bank syariah hanya mengenakan biaya penitipan barang tanpa berkewajiban memberikan imbalan. Sedangkan akad yang mempunyai kesepakatan dalam kerjasama pemilik dan pengelola disebut dengan akad mudharabah.

\section{METODE PENELITIAN}

1. Uji Validitas dan reliabilitas

Alat ukur untuk tingkat keandalan dan kesahihan digunakan dalam sebuah penelitian disebut dengan uji validitas. Jika data yang diukur itu valid, maka itu berarti alat ukur valid digunakan untuk apa yang seharusnya diukur. (Zahreze,dkk, 2014:177) Instrumen yang valid merupakan instrumen yang benar-benar tepat untuk mengukur apa yang hendak diukur. Validitas yang digunakan adalah membandingkan $r$ hitung $>$ 0,361 dalam penelitian ini.

Uji reliabilitas merupakan alat ukur kuesioner yang merupakan indikator dari sebuah variabel. Jika jawaban responden pada penelitian konsisten atau stabil maka kuesioner tersebut dinyatakan reliabel. Jika alat ukur tersebut konsisten tidak berubah dari waktu ke waktu artinya alat ukur tersebut andal digunakan dalam penelitian(Janti, 2014:155). Uji realiabilitas dari masing-masing instrumen pengukuran menggunakan uji cronbach's alpha. Kuesioner dikatakan reliabilitas apabila nilai koefisien alpha lebih besar dari 0,60 ( $a>0,60)$

\section{Analisis Faktor}

Teknik analisis data yang digunakan dalam penelitian ini adalah analisis faktor. Analisis faktor didefinisikan sebagai analisis multivariat yang memiliki fungsi untuk 
menentukan satu atau beberapa variabel. Selain itu, metode ini juga dapat digunakan untuk mengetahui suatu faktor dominan dalam suatu masalah. Analisis faktor diuji terlebih dahulu dengan menggunakan uji Kaiser Mayer Olkin (KMO). Uji KMO digunakan untuk menunjukan apakah metode sampling yang digunakan memenuhi syarat kecukupan data dan mengukur kecukupan sampel secara menyeluruh atau tidak. (Alhifni, 2017:410)

Dalam melakukan analisis faktor, memiliki $\mathrm{p}$ buah variabel, yaitu $\mathrm{X}_{1}, \mathrm{X}_{2}, \mathrm{X}_{3, \ldots}, \mathrm{X}_{\mathrm{P}}$, Maka faktor dapat dituliskan secara matematis sebagai kombinasi linier dari variabel tersebut, dengan formulsi:

$$
\begin{aligned}
& \mathrm{F}_{1}=\mathrm{a}_{11} \mathrm{X}_{1}+\mathrm{a}_{12} \mathrm{X}_{2}+{ }_{\mathrm{a} 13} \mathrm{X}_{3}+\ldots . .+{ }_{\mathrm{a} 1 \mathrm{p}} \mathrm{X}_{\mathrm{p}} \\
& F_{2}={ }_{a 21} X_{1}+{ }_{a 22} X_{2}+{ }_{a 23} X_{3}+\ldots . .+a 2 p X p \\
& F_{1}=a_{11} X_{1}+a_{12} X_{2}+{ }_{a 13} X_{3}+\ldots . .+{ }_{a 1 p} X_{p}
\end{aligned}
$$

Faktor yang terbentuk dari variabel ini bisa berjumlah satu atau lebih, tergantung hasil perhitungan yang dilakukan. Jumlah faktor yang didapat, tentunya akan lebih kecil dibandingkan variabel aslinya. Variabel-variabel tersebut akan direduksi sehingga membentuk beberapa faktor. Oleh karena itu, reduksi variabel dapat dilakukan dengan mempertahankan keragaman (variasi) data asli sebesar mungkin dan akan terbentuk dengan sendirinya suatu faktor.

\section{Populasi dan Sampel}

Wilayah generalisasi yang memiliki kuantitas dan karakteristik objek atau subjek tertentu yang memiliki kuantitas dan karakteristik yang sudah ditetapkan dengan hasil akhir yang ditarik berupa kesimpulan adalah sebuah populasi. Sampel adalah perwakilan dari populasi, atau bagian kecil dari anggota populasi yang karakteristik nya dimiliki oleh populasi tersebut.

Dalam penelitian ini teknik sampel dengan menggunakan teknik sampling bertujuan atau purposive sampling. Cara pengambilan suatu subjek yang buka didasarkan atas random, stara atau daerah tertentu disebut dengan cara purposive sampling (Arikunto, 2010:183) atau berarti setiap subjek yang diambil dari populasi atas tujuan dan pertimbangan tertentu.

\section{Objek dan Lokasi Penelitian}

Objek dari penelitian ini adalah Lembaga Pendidikan Islam yang ada di Sukabumi Jawa Barat. 


\section{Teknik Pengumpulan Data}

1. Kuesioner

Dalam penelitian ini, teknik pengumpulan data yang digunakan adalah:

Kuesioner, Salah satu metode pengumpuln data dengan memberikan lembaran angket yang berisi pernyataan kepada responden disebut dengan kuesioner. Kuesioner juga dapat diartikan pengajuan pertanyaan melalui proses komunikasi untuk memperoleh data yang dilakukan oleh peneliti (Pujihastuti, 2010:44).

Jenis kuesioner dalam penelitian ini yaitu kuesioner tertututp atau kuesioner yang memungkinkan responden memilih alternative jawaban yang telah disediakan. Kuesioner dalam penelitian ini menggunakan skala likert, yaitu skala pengukuran sikap responden terhadap sesuatu, Untuk penilaian pada tiap jawaban yang diberikan oleh responden, maka peneliti menentukannya sebagai berikut :

Tabel 1

\begin{tabular}{ccc} 
& Skala Likert & \\
\hline Katagori & Simbol & Bobot Nilai \\
Sangat Setuju & SS & 4 \\
Setuju & S & 3 \\
Tidak Setuju & TS & 2 \\
Sangat Tidak Setuju & STS & 1 \\
\hline
\end{tabular}

2. Wawancara

Menurut (Sugiyono, 2013:194) teknik pengumpulan data yang dilakukan peneliti dengan melaksanakan studi pendahuluan untuk mencari permasalahan yang harus diteliti dan juga jika peneliti ingin mengetahui lebih mendalam tentang responden dilakukan dengan cara wawancara atau interview.

\section{HASIL DAN PEMBAHASAN}

\section{Uji Validitas dan Reliabilitas}

\section{a. Uji Reliabilitas}

Uji reliabilitas dari semua faktor menggunakan Cronbach Alpha. Kuesioner dinyatakan reliabel jika nilai koefisien alpha lebih besar $>0,6$. Hasil nilai koefisien dapat dilihat pada tabel berikut: 
Tabel 2 Reliability Statistics

Cronbach'sAl

pha $\quad \mathrm{N}$ of Items

,943 $\quad 30$

Tabel diatas memiliki Cronbach Alpha sebesar 0,943 di atas 0,60 maka instrumen dinyatakan reliabel.

\section{b. Uji Validitas}

Uji validitas dilakukan untuk menguji kuesioner layak untuk digunakan sebagai instrument penelitian. Kriteria validitas yaitu korelasi masing-masing pernyataan dengan nilai Corrected Item Total Correlation lebih besar atau sama dengan 0,361. Hasil uji validitas dengan SPSS 22 dapat diuraikan pada tabel berikut:

Tabel 3.

Validitas Instrumen Penelitian

\begin{tabular}{|c|c|c|c|c|}
\hline & $\begin{array}{l}\text { Scale Mean if } \\
\text { Item Deleted }\end{array}$ & $\begin{array}{l}\text { Scale } \\
\text { Variance if } \\
\text { Item Deleted }\end{array}$ & $\begin{array}{l}\text { Corrected } \\
\text { Item-Total } \\
\text { Correlation }\end{array}$ & $\begin{array}{l}\text { Cronbach's } \\
\text { Alpha if Item } \\
\text { Deleted }\end{array}$ \\
\hline AG7 & 94,15 & 114,239 & ,390 & ,943 \\
\hline LK3 & 94,35 & 112,766 & ,424 & ,943 \\
\hline PD1 & 93,95 & 112,892 & ,518 & ,942 \\
\hline PD2 & 94,15 & 111,818 & ,622 & ,941 \\
\hline PD3 & 94,20 & 111,747 & ,531 & ,941 \\
\hline PD4 & 94,40 & 110,779 & ,423 & ,944 \\
\hline KR1 & 94,85 & 108,871 & 607 & ,941 \\
\hline KR3 & 94,65 & 109,082 & ,498 & ,943 \\
\hline PS1 & 94,45 & 110,261 & 699 & ,940 \\
\hline PS3 & 94,60 & 111,411 & ,469 & ,942 \\
\hline FL1 & 94,05 & 111,103 & ,676 & ,940 \\
\hline FL3 & 94,20 & 111,958 & ,626 & ,941 \\
\hline FL4 & 94,10 & 111,674 & ,520 & ,942 \\
\hline FL6 & 94,00 & 111,474 & ,645 & 940 \\
\hline PL1 & 94,05 & 112,261 & ,566 & ,941 \\
\hline PL2 & 94,15 & 109,924 & ,807 & ,939 \\
\hline PL3 & 94,45 & 112,787 & ,600 & ,941 \\
\hline PL4 & 94,20 & 111,326 & 689 & ,940 \\
\hline PL5 & 94,30 & 109,063 & 690 & ,940 \\
\hline PL6 & 94,25 & 109,461 & ,744 & ,939 \\
\hline PL7 & 94,10 & 110,305 & ,757 & ,939 \\
\hline PT1 & 94,25 & 110,618 & ,552 & ,941 \\
\hline
\end{tabular}


Hardiyani dkk | Jurnal Ekonomi dan Bisnis Islam, Vol. 4, No. 2, Juni - Desember 2018

\begin{tabular}{lllll} 
& $\begin{array}{c}\text { Scale Mean if } \\
\text { Item Deleted }\end{array}$ & $\begin{array}{c}\text { Scale } \\
\text { Variance if } \\
\text { Item Deleted }\end{array}$ & $\begin{array}{c}\text { Corrected } \\
\text { Item-Total } \\
\text { Correlation }\end{array}$ & $\begin{array}{c}\text { Cronbach's } \\
\text { Alpha if Item } \\
\text { Deleted }\end{array}$ \\
\hline PT2 & 94,30 & 111,800 &, 711 &, 940 \\
PT4 & 94,60 & 109,200 &, 561 &, 941 \\
PM1 & 94,50 & 113,737 &, 570 &, 941 \\
PM2 & 94,60 & 108,884 &, 747 &, 939 \\
PM3 & 94,65 & 108,345 &, 657 &, 940 \\
IM1 & 94,05 & 111,839 &, 504 &, 942 \\
IM2 & 94,05 & 113,629 &, 362 &, 943 \\
IM3 & 94,35 & 110,345 &, 734 &, 940 \\
\hline
\end{tabular}

Sumber : Data diolah,2018

Dari hasil pengolahan data diatas, yang di uji pada 20 responden yaitu dari 45 pernyataan terdapat 30 pernyataan yang valid atau lebih dari $>0,361$ dan dapat dioleh lebih lanjut.

\section{Analisis Faktor}

Dalam penelitian ini menggunakan 30 pernyataan pada kuesioner yang mengarah pada variabel atau faktor mana yang paling dominan mempengaruhi lembaga pendidikan Islam dalam memilih payroll di bank syariah. Metode analisis data yang digunakan adalah metode analisis faktor dengan SPSS versi 22 untuk lebih jelasnya seperti tahapan berikut ini:

\section{a. Uji Kaiser Mayer Olkin (KMO)}

Langkah pertama dari pengolahan analisis faktor adalah menilai variabel yang layak dan telah diuji validitasnya untuk dimasukan kedalam analisis selanjutnya. Dari pengolahan data oleh SPSS 22 diperoleh hasil pengolahan data yang ditunjukan oleh tabel berikut:

Tabel 4

$\mathrm{KMO}$ and Bartlett's Test

\begin{tabular}{lcl}
\hline $\begin{array}{l}\text { Kaiser-Meyer-Olkin } \\
\text { Adequacy. }\end{array}$ & Measure of Sampling & \\
Bartlett's Test & of Approx. Chi-Square & 176,972 \\
Sphericity & Df & 45 \\
& Sig. &, 000 \\
\hline
\end{tabular}

Sumber : Data diolah,2018

Dari tabel diatas diperoleh angka Kaiser MeyerOlkin Measure of Sampling Adequacy (K-M-O MSA) mencapai 0,732 hasil ini termasuk hasil yang baik mengingat angka ini sudah di atas 0,5. Nilai Bartlett's Test of Sphericity mempunyai nilai 176,972 
dengan signifikansi 0,000 nilai ini berarti bahwa faktor pembentuk sudah baik dan bisa dianalisis lebih lanjut.

\section{b. Proses Ekstraksi}

Proses ekstraksi ini merupakan proses inti dari analisis faktor, metode pembuatan faktor (ektraksi variabel) dengan menggunakan Principal Components dan proses rotasi dengan menggunakan metode rotasi Orthogonal yaitu varimax melakukan ekstraksi terhadap sekumpulan variabel yang telah lolos uji validitas sebelumnya, sehingga terbentuk satu atau lebih faktor. Pada proses ektraksi faktor ini menggunakan SPSS 22 dengan metode ektraksi Principal Componen Analysis (PCA), dengan tingkat Eigenvalues over $=1$, yang artinya item dengan angka eigenvalues dibawah ini akan dikeluarkan. Dari ektraksi ini didapat tabel Communalities, Tabel Total Variance Explained, tabel Rotated Component Matrix sebagai berikut:

Tabel 5

\begin{tabular}{lll} 
& \multicolumn{3}{c}{ Communalities } \\
\cline { 2 - 3 } & Initial & $\mathrm{n}$ \\
\hline Agama & 1,000 &, 456 \\
Lokasi & 1,000 &, 751 \\
Produk & 1,000 &, 597 \\
Kelompok & 1,000 &, 459 \\
Referensi & 1,000 &, 527 \\
Peran dan Status & 1,000 &, 767 \\
Fasilitas & 1,000 &, 826 \\
Pelayanan & 1,000 &, 670 \\
Pengetahuan & 1,000 &, 900 \\
Promosi & 1,000 &, 581 \\
Image &
\end{tabular}

Sumber : Data diolah,2018

Nilai intial merupakan varian variabel sebelum dilakukan ekstrak. Semua nilai intial bernilai 1, hal ini berarti bahwa sebelum dilakukan ektraksi variabel tersebut $100 \%$ membentuk faktor tersebut, karena faktor sebelumnya dilakukan ektraksi adalah sama dengan variabel. Nilai extraction menggambarkan besar presentase varian sesuai variabel yang dapat dijelaskan oleh variabel yang terbentuk. Faktor agama memiliki nilai extraction yaitu sebesar 45,6\%, lokasi memiliki nilai extraction yaitu sebesar 75,1\%, produk memiliki nilai extraction yaitu sebesar 59,7, kelompok referensi memiliki nilai extraction yaitu sebesar $45,9 \%$, peran dan status memiliki nilai extraction yaitu sebesar $52,7 \%$, fasilitas memiliki nilai extraction yaitu sebesar $76,7 \%$, pelayanan memiliki nilai extraction yaitu sebesar $82,6 \%$, pengetahuan memiliki nilai extraction yaitu sebesar 
$67,0 \%$, promosi memiliki nilai extraction yaitu sebesar $90,0 \%$ dan image memiliki nilai extraction yaitu sebesar $58,1 \%$.

Dapat dilihat sebenarnya berapakah faktor yang terbentuk dari 10 variabel tersebut. Tabel dibawah ini akan menjelaskannya, berdasarkan pengolahan SPSS 22 didapat hasil bahwa 10 variabel yang digunakan dalam penelitian ini akan dikelompokan dalam 2 faktor, sebagaimana yang tertera pada tabel berikut ini:

Tabel 6.

Total Variance Explained

\begin{tabular}{|c|c|c|c|c|c|c|c|}
\hline \multirow[b]{2}{*}{$\begin{array}{l}\text { Compone } \\
\mathrm{nt}\end{array}$} & \multicolumn{3}{|c|}{ Initial Eigenvalues } & \multicolumn{3}{|c|}{$\begin{array}{l}\text { Extraction } \\
\text { Loadings }\end{array}$} & \multirow{2}{*}{$\begin{array}{l}\text { Rotation } \\
\text { Sums of } \\
\text { Squared } \\
\text { Loadings }^{\text {a }}\end{array}$} \\
\hline & Total & $\begin{array}{l}\% \text { of } \\
\text { Variance }\end{array}$ & $\begin{array}{l}\text { Cumulativ } \\
\text { e \% }\end{array}$ & Total & $\begin{array}{l}\% \\
\text { Variance }\end{array}$ & $\begin{array}{l}\text { of Cumulativ } \\
\text { e } \%\end{array}$ & \\
\hline 1 & 5,027 & 50,269 & 50,269 & 5,027 & 50,269 & 50,269 & 4,488 \\
\hline 2 & 1,507 & 15,073 & 65,342 & 1,507 & 15,073 & 65,342 & 3,364 \\
\hline 3 & 984 & 9,836 & 75,178 & & & & \\
\hline 5 & ,527 & 5,268 & 88,436 & & & & \\
\hline 6 & ,464 & 4,636 & 93,072 & & & & \\
\hline 7 & ,306 & 3,060 & 96,132 & & & & \\
\hline 8 & 183 & 1,828 & 97,960 & & & & \\
\hline 9 & ,125 & 1,249 & 99,209 & & & & \\
\hline 10 & 079 & ,791 & 100,000 & & & & \\
\hline \multicolumn{8}{|c|}{ Sumber : Data diolah,2018 } \\
\hline
\end{tabular}

Berdasarkan output total variance explained dapat diketahui bahwa :

a. Faktor pertama yang memiliki nilai eigenvalue sebesar 5,027 dengan varian 50,269 persen.

b. Faktor kedua memiliki nilai eigenvalue sebesar 1,507 dengan varian 15,073 persen.

Hasil tersebut menunjukan bahwa faktor 1 mampu menjelaskan seluruh varians sebesar 50,269\% dan faktor 2 mampu menjelaskan seluruh varians sebesar 15,073\%. Adapun berdasarkan komulatif seluruh faktor dapat dijelaskan varians sebesar 65,342 persen.

Setelah didapat 2 faktor yang merupakan jumlah yang paling ideal, maka analisis selanjutnya dilakukan pada component matrix yang merupakan faktor of loading yang menunjukan besar korelasi antara suatu variabel dengan faktor pertama dan faktor kedua. Proses penentuan variabel asal pada faktor dilakukan dengan membandingkan 
besar korelasi tiap baris yang didasarkan pada angka mutlak factor of loading yang memberikan setiap indikator terhadap masing-masing faktor.

Berdasarkan component matrix, bahwa keseluruhan indikator berada pada faktor 1 dengan nilai factor of loading lebih dari 0,5 dan tidak ada indikator yang masuk kepada faktor 2 karena keseluruhan nilai factor of loading kurang dari 0,5. Padahal syarat suatu indikator masuk ke dalam suatu faktor yaitu factor of loading harus di atas 0,5. Maka dari itu, perlu adanya proses rotasi agar component 2 memiliki nilai factor of loading yang besar, sehingga dapat terlihat variabel mana yang masuk pada component 2 . Proses rotasi menggunakan metode varimax yang bertujuan untuk memperbesar nilai factor of loading yang awalnya memang sudah besar dan memperkecil nilai factor of loading yang awalnya memang sudah kecil, sehingga diperoleh distribusi factor of loading yang ditunjukan oleh tabel 7 berikut ini:

Tabel 7

Rotated Component Matrix

\begin{tabular}{|c|c|c|}
\hline \multirow[t]{3}{*}{ Structure Matrix } & \multirow{2}{*}{\multicolumn{2}{|c|}{ Component }} \\
\hline & & \\
\hline & 1 & 2 \\
\hline Pelayanan & ,902 & 458 \\
\hline Fasilitas & ,864 & ,213 \\
\hline Image & ,761 & ,339 \\
\hline Agama & 675 & ,254 \\
\hline Kelompok & 674 & 206 \\
\hline Referensi &, 014 &,$<00$ \\
\hline Peran dan Status & 656 & ,547 \\
\hline Produk & 648 & 645 \\
\hline Promosi & 359 & 949 \\
\hline Lokasi & 244 & ,860 \\
\hline Pengetahuan & ,631 & ,730 \\
\hline
\end{tabular}

Sumber : Data diolah, 2018

Setelah dilakukan rotasi, maka dapat dengan mudah menentukan indikatorindikator mana yang akan masuk kedua faktor tersebut. Dari hasil rotated component matrix dapat dilihat bahwa variabel yang termasuk dalam component 1 yaitu indikator pelayanan $(0,902)$, fasilitas $(0,864)$, image $(0,761)$, agama $(0,675)$ dan kelompok referensi $(0,674)$. Hasil ini dinyatakan bahwa indikator tersebut mempunyai korelasi yang tinggi terhadap faktor 1 . Kemudian untuk component 2 yaitu indikator peran dan status $(0,547)$, produk $(0,645)$, promosi $(0,949)$, lokasi $(0,860)$ dan pengetahuan $(0,730)$.

Hasil analisis faktor dengan 10 indikator yang diteliti menggunakan metode ekstraksi principle component analysis yang direduksi menjadi 2 faktor dimana indikator 
pelayanan, fasilitas, image, agama, dan kelompok referensi menjadi faktor 1 . Sedangkan peran dan status, produk, promosi, lokasi dan pengetahuan masuk kepada faktor 2 .

Tabel 8

Faktor-faktor yang mempengaruhi preferensi lembaga pendidikan Islam dalam memilih payroll di bank syariah

\begin{tabular}{ccccc}
\hline Faktor & $\begin{array}{c}\text { Variabel } \\
\text { Asal }\end{array}$ & $\begin{array}{c}\text { Nilai Factor } \\
\text { of Loading }\end{array}$ & Eigenvalues & Varians (\%) \\
\hline \multirow{4}{*}{ Faktor 1 } & Pelayanan & 0,902 & & \\
& Fasilitas & 0,864 & & \\
& Image & 0,761 & 5,027 & $50,269 \%$ \\
& Agama & 0,675 & & \\
& Kelompok & 0,674 & & \\
& Referensi & & & $15,073 \%$ \\
Faktor 2 & Peran dan & 0,547 & & \\
& status & & & \\
& Produk & 0,645 & 1,507 & \\
& Promosi & 0,949 & & \\
& Lokasi & 0,860 & & \\
& Pengetahuan & 0,730 & & \\
\hline
\end{tabular}

Sumber : Data diolah,2018

Faktor pertama ini memiliki nilai eigenvalue sebesar 5,027, bahwa faktor ini merupakan faktor yang paling dominan atau yang paling mempengaruhi preferensi lembaga pendidikan Islam dalam memilih payroll di bank syariah. Faktor 1 menerangkan keragaman data sebesar 50,269 persen. faktor ini dinamakan "personal influence" yaitu faktor pengaruh yang lebih bersifat personal decision, atau disebut juga dengan mempengaruhi keputusan suatu individu karena sebuah preferensi personal terhadap suatu aspek seperti pelayanan,fasilitas, image,agama dan kelompok referensi.

Sedangkan faktor kedua memiliki nilai eigenvalue sebesar 1,507, bahwa faktor ini merupakan faktor pendukung dalam mempengaruhi preferensi lembaga pendidikan Islam dalam memilih payroll di bank syariah. Faktor 2 menerangkan keragaman data sebesar 15,073 persen. faktor ini dinamakan dengan "produk influence" atau yang berkaitan dengan sebuah usaha-usaha yang dilakukan oleh sebuah perusahaan untuk meningkatkan awereness dari nasabah terhadap suatu produk, dengan membangun sebuah ingatan, sebuah loyalitas yang tinggi dan memberikan suatu kemudahan yang menjadi effort yang dilakukan sebuah perusahaan atau dalam hal ini bank syariah. 


\section{SIMPULAN}

Setelah melakukan penelitian mengenai preferensi lembaga pendidikan Islam dalam memilih payroll di bank syariah di Sukabumi, terdapat beberapa kesimpulan dan saran yang dapat dijelaskan, yaitu:

1. Perlu adanya dukungan dari pemerintah untuk menggunakan bank syariah sebagai penyalur gaji atau payroll sehingga jika pemerintah sudah membuat ketentuan untuk menggunakan payroll di bank syariah maka akan lebih mudah untuk bank syariah dan lembaga pendidikan Islam maupun lembaga pendidikan lainnya mau tidak mau pasti akan menggunakan bank syariah.

2. Untuk penelitian selanjutnya, jika dengan tema atau konsep yang sama maupun tidak sampai hanya mengetahui faktor dominannya saja namun bisa dilanjutkan dengan menghitung preferensinya, dan dapat ditambahkan dengan variabel yang belum ada pada penelitian ini, seperti variabel faktor ekonomis untuk hasil penelitian yang variatif mengenai preferensi terhadap bank syariah.

\section{DAFTAR PUSTAKA}

Agustina, S. (2013). Sekolah Islam Terpadu Dalam Pembentikan Karakter Religius Siswa. Bandar Lampung: Universitas Lampung.

Aisyah Erninda, S. K. (2016). Faktor-faktor Preferensi Pelanggan dan Kebutuhannya Terhadap Keputusan Pembelian. Jurnal Administrasi Bisnis (JAB) Vol. 30 No. 1, 8795.

Alhifni, N. H. (2017). Faktor-faktor yang Mempengaruhi Motivasi Mahasiswa Menjadi Enterpreneur Syariah. Jurnal Syarikah Volume 3 No 1 , 403-418.

Ananta, B. (2016). Implementasi Payroll dalam Pemberian Gaji Karyawan yang Berakad Wadi'ah di Bank BRI Syariah Purwakerto . Purwakerto: Institut Agama Islam Negeri (IAIN).

Arikunto. (2010). Prosedur Penelitian: Suatu Pendekatan Praktek. Jakarta: Rineka Cipta.

Atsari, I. N. (2013). Analisis Terhadap Produk Payroll Studi Kasus di Bank Syariah Mandiri Salatiga. Salatiga: SEKOLAH TINGGI AGAMA ISLAM NEGERI ( STAIN) SALATIGA.

Bafadhol, I. (2017). Lembaga Pendidikan Islam. Jurnal Edukasi Islam Jurnal Pendidikan Islam Vol. 06 No.11 Januari, 59-72.

Haris, M. (2015). Analisis Faktor-faktor yang Mempengaruhi Preferensi Nasabah Terhadap Bank Syariah di DKI Jakarta. Bogor : Institut Pertanian Bogor .

Herman, D. (2013). Sejarah Pesantren di Indonesia . Jurnal Al-Ta'dib Vol. 6 No. 2 JuliDesember, 145-158. 
Ibrahim, Z. (2013). Stategi Mendorong Pertumbuhan Bank Syariah . Banten: Fakultas Syari'ah dan Ekonomi Islam IAIN Sultan.

Janti, S. (2014). Analisis Validitas dan Reliabilitas Dengan Skala Likert Terhadap Pengembangan SI/TI Dalam Penentuan Pengambilan Keputusan Penerapan Strategic Planning pada Industri Garmen . Proseding Seminar Nasional Aplikasi Sains \& Teknologi (SNAST) , 155-160.

Kotler, P. (2000). Manajemen Pemasaran . Jakarta: Prehalindo Cet ke-10.

Pujihastuti, I. (2010). Prinsip Penulisan Kuesioner Penelitian . Jurnal Agribisnis dan Pengembangan Wilayah Vol. 2 No. 1 , 43-56.

Rahmawati, R. F. (2016). Kaderisasi Dahwah Melalui Lembaga Pendidikan Islam. Jurnal Manajemen Dakwah TADBIR Vol. 1 No. 1 , 147-166.

Ridwan Arif Setiawan, S. H. (2016). Analisis Faktor-faktor yang Mempengaruhi Nasabah dalam Menggunakan Produk Jasa Perbankan Syariah (Studi PT Bank Negara Indonesia Cabang Sukabumi). Jurnal Nisbah Vol. 2 No. 1, 221-236.

Rouf, M. (2016). Memahami Tipologi Pesantren dan Madrasah sebagai Lembaga Pendidikan Islam Indonesia. Memahami Tipogi Pesantren , 68-92.

Sugiyono. (2013). Metode Penelitian Kuantitatif, Kualitatid dan R\&D. Bandung: Alfabeta. CV.

Zahreze Fajar Setiara Putra, M. S. (2014). Analisis Kualitas Layanan Website BTKP-DIY Menggunakan Metode WEBQUAL 4.0 . Jurnal JARKOM Vol. 1 No. 2 , 174-184. 